\title{
The Evolution of Linguistic Policies and Practices of the Austro-Hungarian Armed Forces in the Era of Ethnic Nationalisms: The Case of Ljubljana-Laibach
}

\author{
Rok Stergar
}

As nationalisms evolved during the nineteenth century, the understanding of languages changed dramatically. What used to be primarily a tool for communication and - in certain cases - a social marker was transformed into a political symbol, "an instrument of the "cult of nation," as Peter Burke put it. This process of the politicization of language had a great impact on the linguistically diverse Austrian Empire and Austria-Hungary. One of the most visible changes in language use and the linguistic landscape was in regard to public inscriptions and signs in many towns in the lands with a non-Germanspeaking majority. The earlier domination of German in urban settings, especially in public, had become unacceptable as non-German nationalists moved to nationalize cities and towns. Thus, they strived to achieve one of their principal goals: a national space that would include all their compatriots but nobody else. ${ }^{2}$

As such a result was hardly possible in reality, the process was fraught with conflict. Not only German-speaking minorities, but also the Austrian state was for the most part not willing to give up German completely, the language that they generally considered to be superior. In this chapter, I will try to deepen our understanding of these developments by establishing how, if at all, the activities of Slovene nationalists in the capital of Carniola, Ljubljana-Laibach, were reflected in the changes of military rules and regulations as well as common practices. I hope to provide an answer to this question by analyzing

* I would like to thank the participants of the 2014 conference "Urban Space and Multilingualism in the Late Habsburg Empire" held at the University of Vienna for their helpful comments. I would also like to acknowledge the financial support from the Slovenian Research Agency (research core funding No. P6-0235).

1 Peter Burke, Languages and Communities in Early Modern Europe (Cambridge: Cambridge University Press, 2004), 160. For a comprehensive modern overview of those transformations in Central Europe, see Tomasz Kamusella, The Politics of Language and Nationalism in Modern Central Europe (Basingstoke: Palgrave Macmillan, 2009).

2 Ernest Gellner, Nations and Nationalism, 2nd ed. (Oxford: Blackwell, 2006), 1-3. 
autobiographical sources, contemporary newspapers, statistics, and military documents from the archives and contextualizing them with the help of existing research. Fortunately, the changes nationalisms brought to urban settings have already been described and analyzed in several books on multilingual towns in the age of nationalism. They differ in their ambition and research outlook but all of them bring a wealth of insight. ${ }^{3}$ There is also some valuable research on Austrian garrison towns, although as Nicola Fontana quite rightly remarked, the literature on their counterparts in Germany is much more extensive and methodologically diverse. ${ }^{4}$ But let me begin with a description of

3 Eleonóra Babejová, Fin-de-Siècle Pressburg: Conflict \& Cultural Coexistence in Bratislava 1897-1914 (Boulder, CO: East European Monographs, 2003); Robert Nemes, The Once and Future Budapest (Dekalb, IL: Northern Illinois University Press, 2005); Markian Prokopovych, Habsburg Lemberg: Architecture, Public Space, and Politics in the Galician Capital, 17721914 (West Lafayette, IN: Purdue University Press, 2008); Gary B. Cohen, The Politics of Ethnic Survival: Germans in Prague, 1861-1914, 2nd rev. ed. (West Lafayette, IN: Purdue University Press, 2006); Jeremy King, Budweisers into Czechs and Germans: A Local History of Bohemian Politics, 1848-1948 (Princeton: Princeton University Press, 2002); Janez Cvirn, Das "Festungsdreieck": zur politischen Orientierung der Deutschen in der Untersteiermark (1861-1914), ed. Ernst Bruckmüller et al., trans. Irena Vilfan-Bruckmüller (Vienna: LIT, 2016); Dragan Matić, Nemci v Ljubljani: 1861-1918 [The Germans of Ljubljana: 1861-1918] (Ljubljana: Historia, 2002); Karin Almasy, Wie aus Marburgern "Slowenen" und "Deutsche" wurden: ein Beispiel zur beginnenden nationalen Differenzierung in Zentraleuropa zwischen 1848 und 1861 (Bad Radkersburg; Graz: Pavelhaus, 2014).

4 Frank Wiggermann, K.u.K. Kriegsmarine und Politik: Ein Beitrag zur Geschichte der italienischen Nationalbewegung in Istrien (Vienna: Verlag der Österreichischen Akademie der Wissenschaft, 2004); Rok Stergar, "Vojski prijazen in zaželen garnizon": Ljubljanski častnikimed prelomom stoletja in prvo svetovno vojno ["A military-friendly and desired garrison town": The officers of Ljubljana from the turn of the century to the First World War] (Ljubljana: Zveza zgodovinskih društev Slovenije, 1999); Wilhelm Steinböck, ed., Graz als Garnison: Beiträge zur Militärgeschichte der steirischen Landeshauptstadt (Vienna: Leykam, 1982); Martin Parth, "Die Garnison Graz um 190o," Historisches Jahrbuch der Stadt Graz 27/28 (1998): 165-89; Nicola Fontana, "Trient als Festungs- und Garnisonsstadt: Militär und zivile Bevölkerung in einer k. u. k. Festungsstadt 1880-1914," in Glanz-Gewalt_Gehorsam:Militär und Gesellschaft in der Habsburgermonarchie (180o bis 1918), ed. Laurence Cole, Christa Hämmerle, and Martin Scheutz (Essen: Klartext, 2010), 177-98; Peter Melichar, "Ästhetik und Disziplin: Das Militär in Wiener Neustadt 1740-1914," in Die Wienerische Neustadt: Handwerk, Handel und Militär, ed. Sylvia Hahn and Karl Flanner (Vienna, Cologne, Weimar: Böhlau, 1994), 283336; Piotr Galik, "Miasta Galicyskie jako garnizony armii austro-węgierskiej w prezededniu I wojny światowej" [The Galician towns as garrisons of the Austro-Hungarian army on the eve of the First World War], Acta Uniwersitatis Wratislaviensis 111 (1993): 113-23; John Fahey, "Undermining a Bulwark of the Monarchy: Civil-Military Relations in Fortress Przemyśl (1871-1914)," Austrian History Yearbook 48 (2017): 145-58; Elisabeth Berger and Laurence Cole, eds., Garnisonsstädte in der Habsburgermonarchie: Militär und Zivilgesellschaft im langen 19. Jahrhundert (Paderborn: Schöningh, forthcoming). For literature on Germany, see Fontana, “Trient als Festungs- und Garnisonsstadt," 177-9. 
starting points: the use of languages in Ljubljana-Laibach and the viewpoints of both the army and the townspeople concerning them.

Ever since the Counts of Spanheim established an urban settlement on the banks of the Ljubljanica sometime in the thirteenth century, the inhabitants of the town used several vernaculars in their oral and written communication. ${ }^{5}$ According to the seventeenth-century polymath Johann Weichard Valvasor, almost a dozen different vernaculars could be heard in the town in his time. Of course, most of them were used only in private, in the homes of foreigners who represented about a third of the town's population. In public, Italian, German, and Slovene were regularly spoken, or as Valvasor put it: "In Laybach, the customary vernaculars are generally Carniolan and German, but the nobles and merchants also use Italian." ${ }^{\prime 6}$

Although a sizable part of the population of Ljubljana-Laibach was able to use several vernaculars or was at least bilingual, the native language of the majority had always been the Slavic vernacular we now call Slovene. Some form of German, on the other hand, was the first language of a significant minority, about a quarter of the population. It was the preferred spoken language of the upper class, although most Carniolan burghers and nobles could also speak Slovene and typically had a soft spot for "our Carniolan language." As a written language, German had an even larger role. It was predominant in correspondence, education, administration, and-as the role of Italian had been diminishing since the eighteenth century-commerce. Slovene had been used in written form only sporadically, mostly to convey trivial content. ${ }^{7}$ German owed its dominance in written communication and in the upper strata of society to its usefulness, the linguistic competence of the inhabitants of Ljubljana-Laibach, and its prestige. German was more useful because it was spoken, written, and read all over Central Europe. Burghers and nobles were more competent in German, especially in writing, because they were educated in it. In addition, the use of German was a social marker, signifying an elevated status.

5 Boris Golec, "Regionalne razlike v jezikovni podobi prebivalstva slovenskih celinskih mest med 16. in 18. stoletjem" [Regional differences in the language of the residents of Slovene continental towns between the sixteenth and eighteenth centuries], Zgodovinski časopis 57 (2003): $32-5$.

6 "Die gewöhnliche Sprach ist zu Laybach insgemein die Crainerische und Teutsche, auch bey dem Adel und Kaufleuten die Italiänische." Johann Weichard Valvasor, Die Ehre deß Hertzogthums Crain, vol. 11 (Laybach, 1689), 708.

7 Golec, "Regionalne razlike," 23-38; Marko Štuhec, "Iz Lesc v Ljubljano po francosko: Prispevek k poznavanju jezikovne rabe kranjskega plemstva v prvi polovici 18. stoletja" [From Lesce to Ljubljana in French: Linguistic customs of the nobility of Carniola in the first half of the eighteenth century], Zgodovinski časopis 60 (2006): 327-43. 
During the last decades of the eighteenth century, these circumstances gradually began to change as the traditional hierarchy of languages became increasingly questioned. When a Carniolan monk, Marcus (Marko) Pohlin, published his Kraynska grammatika [Carniolan grammar] in 1768 , he put considerable effort into persuading his readers that the Carniolan Slavic language was as useful and as important as any other language. He wrote in his introduction:

Any well-founded language has its praise, fame, and benefit. The human society makes use of the same to its advantage, as well as the opening of thoughts, and the immortalization of things ... We should not be ashamed of our mother tongue, dearest compatriots! It is not as bad as you believe. ${ }^{8}$

In the last decades of the eighteenth and in the beginning of the nineteenth century, the notion that the Carniolan Slavic language could and should be used in every situation gained traction among various local intellectuals, priests, and nobles. As such, they promoted its use in non-traditional contexts, especially in literature and education. Anton Tomaž Linhart adapted two plays, Valentin Vodnik published a collection of poems and-for a short while-a newspaper Lublanske novice [Ljubljana news], and Jurij (Georg) Japelj prepared a new translation of the Bible. The Carniolan Slavic vernacular was also used as the language of instruction in elementary schools and-during the short-lived French administration (1809-1813) —in junior high schools. ${ }^{9}$ Its elevation in the public sphere was also supported by the Catholic Church. The bishop of Ljubljana-Laibach, Karl Herberstein, one of the most prominent proponents of Reform Catholicism in the Monarchy, had been promoting the use of the native language in pastoral and educational activities intended for the "common people."10

8 "Eine jede wohlgegründete Sprach hat ihr Lob, Ruhm, und Nutzen. Die Menschengesellschaft bedient sich derselben zu ihren Vortheil, und Eröffnung der Gedanken sowohl, als auch zur Verewigung der Sachen ... Schämen wir uns nicht unserer Muttersprach liebste Landeßleute! Sie ist nicht so schlecht, als ihr es glaubet." P. Marcus [Marko Pohlin], Kraynska grammatika: Das ist die crainerische Grammatik, oder Kunst die crainerische Sprach regelsrichtig zu reden, und zu schreiben (Laybach: Johann Friedrich Eger, 1768), 3, 11.

$9 \quad$ Peter Štih, Vasko Simoniti, and Peter Vodopivec, Slowenische Geschichte: GesellschaftPolitik-Kultur (Graz: Leykam, 2008), 221-32.

10 Jernej Kosi, Kakoje nastal slovenski narod:Začetki slovenskega nacionalnega gibanja v prvi polovici 19. stoletja [How the Slovene nation was built: The beginnings of the Slovene national movement in the first half of the nineteenth century] (Ljubljana: Sophia, 2013), $146-9$. 
These developments were not isolated to Carniola. In Lower Styria and Southern Carinthia, which also had a Slovene-speaking majority, vernacular enthusiasts sought to improve the standing of their regional variants of Slovene too. Even though provincial patriotism was their primary motivation, there was often a wider dimension to their efforts. Most writers tried to incorporate at least some elements of other variants of Slovene as well as the sixteenth-century Protestant literary tradition into their language."1 They saw their efforts as a step towards a literary language that could transcend the solitary province and have a more universal use. Such endeavors were not new, as the Jesuits had tried to standardize a common South Slavic language starting as early as the fifteenth and sixteenth centuries, ${ }^{12}$ but this time the activists were much more successful. One of the reasons for this success was the support of the Habsburg state for such efforts, though paradoxically ratcheting up competition. On the one hand, Joseph II made German the official language in an effort to streamline the administration of the Habsburg Monarchy and, consequently, the importance and use of German grew..$^{13}$ On the other hand, the authorities were increasingly aware of the importance of local vernaculars for their own educational efforts and communication with their subjects, and therefore they pragmatically supported their standardization and development all over the monarchy. ${ }^{14}$

In the beginning of the nineteenth century, all these activities culminated in the conceptualization of a single Slovene language. Whereas previous scholars mostly distinguished three related but distinct languages-Carniolan, Styrian, and Carinthian Slovene - the linguist Bartholomäus Kopitar claimed that the Slavic vernaculars of Carniola, Southern Carinthia, and Lower Styria (as well as

\footnotetext{
11 Kosi, Kako je nastal slovenski narod, 144-51.

12 Anita Peti-Stančić, "The (Western) South Slavic Language Question Revisited," in A Linguist's Linguist: Studies in South Slavic Linguistics in Honor of E. Wayles Browne, ed. Steven Franks, Vrinda Chidambaram, and Brian Joseph (Bloomington: University of Indiana Press, 2009), 367 .

13 Golec, "Regionalne razlike," 37, 38; Peter Scherber, "Von der Zweisprachigkeit zur Einsprachigkeit: Wegmarken zur Entwicklung der slowenischen Nationalkultur im 19. Jahrhundert," in Die Grundlagen der slowenischen Kultur: Bericht über die Konferenz der Kommission für interdisziplinäre Südosteuropa-Forschung im September 2002 in Göttingen, vol. 6 of Abhandlungen der Akademie der Wissenschaften zu Göttingen, ed. France Bernik and Reinhard Lauer (Berlin: de Gruyter, 2010), 162.

14 Karl Vocelka, Glanz und Untergang der höfischen Welt: Repräsentation, Reform und Reaktion im habsburgischen Vielvölkerstaat, vol. 7 of Österreichische Geschichte 1699-1815 (Vienna: Ueberreuter, 2001), 241, 242, 386; for Carniola and Styria, see Joachim Hösler, Von Krain zu Slowenien: Die Anfänge der nationalen Differenzierungsprozesse in Krain und der Untersteiermark von der Aufklärung bis zur Revolution 1768 bis 1848 (Munich: Oldenbourg, 2006), 143-6.
} 
parts of Croatia) were actually just dialects of a single South Slavic language. ${ }^{15}$ Kopitar's interpretation quickly gained popularity among intellectuals in all these lands, and they made strong efforts to amalgamate existing provincial literary languages into one. Simultaneously they began to call it Slovene (slovenski jezik), using an adjective that previously had held a wider meaning, as it had been generally used in the sense of Slavic. ${ }^{16}$ The new standard language established itself rather quickly in literature and, perhaps most importantly, in the new weekly paper Kmetijske in rokodelske novice [Agricultural and artisanal news], thus establishing an Andersonian unified field of exchange and communication. As the notion that a separate language denotes a separate nation had also been spreading, the idea of a distinct Slovene nation began to take shape in the first decades of the nineteenth century. The shift from assuming provincial identities to a wider Slovene identity can clearly be observed in the private letters of a small group of "patriots," as they liked to call themselves, as well as in their various publications and in Novice. ${ }^{17}$

In March 1848, Slovene national thought, to use Joep Leerssen's term, evolved into Slovene nationalism, as various individuals and smaller groups put forward the demand for the establishment of an autonomous Slovenia, a new Habsburg kingdom that would unite all the lands with a Slovene-speaking population. All the national programs demanded that Slovene be the language of administration, the judiciary, and education in the proposed Slovenia. In a flier, Matija Majar, who was the first to call for a United Slovenia, demanded that (1) the Slovene language should receive the same rights in Slovene lands that the German and Italian languages already enjoyed in German and Italian lands, (2) Slovenes be allowed to introduce Slovene in all offices and schools, "if we want to, when we want to, and however we want to," and (3) every official in Slovenia be fluent in Slovene. ${ }^{18}$

After 1848 , as Slovene nationalism had slowly been gaining ground, the increased role of Slovene in all spheres of life became the principal demand of Slovene nationalists. Even when they, because of unfavorable circumstances or

15 Kosi, Kako je nastal slovenski narod, 151-67.

16 Ibid., 170-89; Hösler, Von Krain zu Slowenien, 152-88; Kamusella, The Politics of Language and Nationalism, 294, 295; Martina Orožen, Oblikovanje enotnega slovenskega knjižnega jezika $v$ 19. stoletju [The establishment of the Slovene literary language in the nineteenth century] (Ljubljana: Filozofska fakulteta, 1996).

17 Kosi, Kako je nastal slovenski narod, 236-36o; Hösler, Von Krain zu Slowenien, 244-70.

18 Matija Majar, “Kaj Slovenci terjamo?," in Janko Prunk, Slovenski narodni programi: Narodni programi $v$ slovenski politični misli od 1848 do 1945 [Slovene national programs: National programs in Slovene political thought from 1848 to 1945] (Ljubljana: Društvo 200o, 1986), $15^{2-9}$. 
political tactics, temporarily abandoned their demands for a United Slovenia, language demands remained an integral part of their platform. ${ }^{19}$ In fact, mirroring a trend seen in other parts of the monarchy, Slovene assumed an everlarger role as it gradually replaced German in the schools and administration. ${ }^{20}$

However, in Ljubljana-Laibach the traditional patterns of language use and the linguistic landscape did not significantly change until the 186os, even though the city was the center of the Slovene national movement and had a Slovene-speaking majority. The upper class still spoke, read, and wrote mostly in German, street and shop signs were all written in German, and German was the language of the town hall. The most important Slovene poet of the period, France Prešeren, described the situation in his German sonnet with a tercet: "Deutsch sprechen in der Regel hier zu Lande/ Die Herrinnen und Herren, die befehlen,/ Slowenisch die, so von dem Dienerstande."21 Other accounts confirm the validity of Prešeren's assertion. In 1836, a newly arrived artisan, a patriotic Czech, needed six weeks to notice that, besides German, some inhabitants of the town spoke a language that strongly resembled his. ${ }^{22}$ A dozen years later, the naturalist Franz Wilhelm Junghuhn, who in 1848 spent a few days in Ljubljana-Laibach on his trip from Trieste (Trst/Triest) to Vienna, noted that the majority of the population spoke German, but "thought Slavic."23 Even after the 1848 "Spring of Nations," the linguistic situation had not changed significantly and Fran Šuklje, the future politician, remembered that "good families" only spoke Slovene with their servants, and that there was but one Slovene-only shop sign. ${ }^{24}$ At least at first sight, until the 186os, the capital of Carniola was still Laibach, "the final little corner of our German fatherland," as Johann Gottfried Seume described it at the beginning of the century. ${ }^{25}$

19 Vasilij Melik, "O nekaterih vprašanjih slovenske politike v začetku šestdesetih let 19. stoletja" [Some remarks on Slovene politics in the beginning of the sixties of the nineteenth century], in Slovenci 1848-1918: razprave in članki [The Slovenes 1848-1918: Papers and articles] (Maribor: Litera, 2002), 229-30.

20 Štih, Simoniti, and Vodopivec, Slowenische Geschichte, 264.

21 A literal English translation: "As a rule, ladies and gentlemen that give orders speak German in this land, and servants Slovene." France Prešeren, "Warum sie, wert," in Poesien: Auswahl deutscher Übersetzungen, ed. Jože Pogačnik (Munich: Trofenik, 1987), 178.

22 Henrik Tuma, Iz mojega življenja: spomini, misli, izpovedi [From my life: Memories, thoughts, declarations], ed. Branko Marušič (Ljubljana: Založba Tuma, 1997), 14.

23 "Die Bewohner sind größtentheils Slaven, die deutsch sprechen und slavisch denken." Franz Wilhelm Junghuhn, Rückreise von Java nach Europa mit der sogenannten englischen Überlandpost: im September und October 1848, trans. J.K. Haßkarl (Leipzig: 1852), 180.

24 Fran Šuklje, Iz mojih spominov [From my memoirs], vol. 1, ed. Vasilij Melik (Ljubljana: Slovenska matica, 1988-1995), 14.

25 "Das letzte Zipfelchen unsers deutschen Vaterlandes." Johann Gottfried Seume, Spaziergang nach Syrakus im Jahre 1802 (Braunschweig; Leipzig: 1803), 68. 
After the constitutional era started, the situation gradually changed, especially after the "Germans," i.e., the liberal Constitutional party, dominated by the German speaking burghers lost the town hall in 1882. Slovene nationalists initiated systematic Slovenification. Slovene replaced German in local administration; it was established in schools, theater, and literature. Bilingual or Sloveneonly signs started to dominate the linguistic landscape, as Slovene assumed the role of the primary spoken language of all the social strata. ${ }^{26}$ Statistical data illustrates the diminishing importance of the German language as the share of those who had indicated it as their language of daily use slowly but steadily declined. In 188o, it was still almost 23 percent, but it fell to just above 15 percent in the next twenty years. ${ }^{27}$ Cases of individuals who indicated German as their language of daily use in 1880 but switched to Slovene in a later census further confirm the trend. ${ }^{28}$

However, the reversal of roles was not complete. German was still too important to be relegated to the purely secondary role of a minority language. It was the de facto state language of the Austrian half of the Monarchy, and it was a language of some 60 million Europeans. Knowledge of German was still nearly indispensable. Therefore, most Slovene-speaking inhabitants of LjubljanaLaibach had at least some familiarity with the language and many were fluent, especially the well educated. ${ }^{29}$ For ardent Slovene nationalists, who were convinced that a language embodied the "soul of a nation," this maintenance of German was a constant irritation. Whereas Kopitar, whose novel classification of Slavic languages was the basis for the establishment of unified Slovene language, had still proclaimed that Slavs should learn German, and Prešeren, the first Slovene poet of note, had written a number of German poems and supported "poetic bilingualism," bilingualism was increasingly rejected in the

26 See the chapter "Čas strmega padca kranjske ustavoverne stranke: 1880-1882" [The period of a steep decline of the Carniolan Constitutional Party: 1880-1882], in Matić, Nemci v Ljubljani, 197-232; Scherber, "Von der Zweisprachigkeit zur Einsprachigkeit," 166; Vlado Valenčič, Zgodovina ljubljanskih uličnih imen [A history of the street names of Ljubljana] (Ljubljana: Zgodovinski arhiv Ljubljana, 1989), 75-137; Marija Lah, "Borba ljubljanske občine za slovensko uradovanje" [The struggle of the municipality of Ljubljana for Slovene administration], Kronika 5 , no. 3 (1957): 139-46.

27 In 1880, 5,658 (22.79\%) out of 24,824 inhabitants indicated German; in 1900, 5,423 (15.23\%) out of 35,60o. Special-Orts-Repertorium von Krain / Obširen imenik krajev na Krajnskem (Vienna: Verlag der k. k. Hof- und Staatsdruckerei, 1884), 1; Gemeindelexikon von Krain: bearbeitet auf Grund der Ergebnisse der Volkszählung vom 31. Dezember 1900 (Vienna: Verlag der k. k. Hof- und Staatsdruckerei, 1905), 2.

28 Vlado Valenčič, "Etnična struktura ljubljanskega prebivalstva po ljudskem štetju 188o" [The ethnic structure of the inhabitants of Ljubljana according to the census of 1880], Zgodovinski časopis 28 (1974): 302-4.

Scherber, "Von der Zweisprachigkeit zur Einsprachigkeit," 166. 
second half of the century. ${ }^{30}$ Slovene nationalists often echoed the claims of the Slovak leader L'udovit Štúr, that bilingualism leads to a flawed characteras did all the other Central European nationalists. ${ }^{31}$ Despite such pressure, bilingualism did not vanish and some Slovene-speaking parents still sent their kids to German-language schools, because knowledge of German was still seen as a necessary condition for a successful career. ${ }^{32}$

In addition, the influence of German on the native spoken language- the Slovene of streets, markets, workshops, coffeehouses, and inns-was still enormous, in spite of all the efforts of nationalist purists. A glass was still glaž (from German Glas) and not kozarec; a stove was šporhet (from German Sparherd) and not štedilnik; a screwdriver šraufenciger (from German Schraubenzieher); a chimneysweep raufenkirer (from German Rauchfangkehrer), and so on. ${ }^{33}$

The point that I am trying to make here is certainly not that the politicization of language had no influence on the population of Ljubljana-Laibach. There is no doubt that nationalism had a very noticeable influence on people's use of language and their understanding of its role. Nationalist demands resonated widely, especially when they addressed longstanding grievances, for example, the possibility of education or communication with authorities in the local native language. However, there were also limits to people's willingness to adapt to a strict and unrealistic code of conduct.

With that in mind, let me move to the other actor in my analysis, the Austrian armed forces. A peculiar feature of the Austrian army was the socalled regimental languages, that is to say, any languages spoken by more than a fifth of the recruits in a particular unit, which were used for the instruction of recruits, and the officers were under the obligation to learn them. ${ }^{34}$ This

30 For Kopitar, see: Hösler, Von Krain zu Slowenien, 146; and for Prešeren, ibid., 223-7; cf. Reinhard Lauer, "France Prešerens Sonett an die Slowenen, die in deutscher Sprache dichten," Münchner Zeitschrift für Balkankunde 7/8 (1991): 75-83.

31 Štúr is quoted in István Fried, "Mehrsprachigkeit und Kulturbeziehungen in Ostmitteleuropa des 18. und 19. Jahrhunderts," Ungarn-Jahrbuch: Zeitschrift für interdisziplinäre Hungarologie 22 (1995/1996): 103.

32 Hösler, Von Krain zu Slowenien, 142.

33 Andrej Studen, Stanovati v Ljubljani: Socialnozgodovinski oris stanovanjske kulture Ljubljančanov pred prvo svetovno vojno [Living in Ljubljana: A sociohistorical outline of the residential culture of the inhabitants of Ljubljana before the First World War] (Ljubljana: Založba Škuc, 1995), 119, 120.

34 Johann Christoph Allmayer-Beck, "Die bewaffnete Macht in Staat und Gesellschaft," in Die Habsburgermonarchie 1848-1918, vol. 5, Die bewaffnete Macht, ed. Adam Wandruszka and Peter Urbanitsch (Vienna: Verlag der Österreichischen Akademie der Wissenschaft, 1987), 98, 99; Tamara Scheer, "Die k.u.k. Regimentssprachen: Eine Institutionalisierung der Sprachenvielfalt in der Habsburgermonarchie (1867/8-1914)," in Sprache, Gesellschaft und 
unique practice had been originally just an innovative solution to a practical problem, but after 1867 it was also based on the constitutional provision that stated that no citizen should be forced to use a language other than his own to communicate with the authorities.

In this regard, the military appeared quite flexible, but other aspects of its rules and regulations were anything but open-minded. The language of command in the Common Army and the Austrian Landwehr (Territorial Army) was German. A single command language was not just a pragmatic solution for an effective leadership, but also a symbol of the army's unity at a time when the armed forces were supposed to act as a bulwark of Habsburg patriotism against the onslaught of various nationalisms. Therefore, any attempts to introduce different languages of command were rejected resolutely by the emperor and his generals. In 1869, a Slovene MP, Lovro Toman, joined a number of other representatives in proposing the introduction of other command languages in the Landwehr, arguing that every soldier should be led in his national language. ${ }^{35}$ The proposal never stood a chance and was defeated by a large margin but must have nevertheless given the generals a major headache, because the transformation of the army into national contingents was their worst nightmare. ${ }^{36}$ This concern was why the military and the emperor tried to nip in the bud any attempts at replacing German as the language of command with other languages. When some Czech reservists deliberately began to use the Czech reply "zde!" instead of the German "hier!" during army maneuvers at the turn of the century, the emperor promptly threatened to impose martial law on the Bohemian Lands if the practice were not discontinued. ${ }^{37}$ The only exception to this rule was the Hungarian Honvéd (and by extension Hrvatsko domobranstvo, the Croatian Territorial Army), because the Hungarians had managed to assert the Hungarian language of command for their militia immediately after the Compromise of $1867 \cdot \cdot^{38}$

Furthermore, German was also the administrative language (Dienstsprache) of the Common Army and the Austrian Landwehr. ${ }^{39}$ As such, it was, among

Nation: Institutionalisierung und Alltagspraxis, ed. Klaas-Hinrich Ehlers et al. (Göttingen: Vandenhoeck \& Ruprecht, 2014), 75-92.

35 Stenographische Protokolle über die Sitzungen des Hauses der Abgeordneten des Reichrathes (SPSHAR), 4th session, 5321-5322, 5380-5382; Slovenski narod, 20 March 1869, 2, 3.

36 Allmayer-Beck, "Die bewaffnete Macht," 85, 86.

37 Gunther E. Rothenberg, The Army of FrancisJoseph (1976; West Lafayette, IN: University of Indiana Press, 1998), 130; Allmayer-Beck, "Die bewaffnete Macht," 86.

38 Gunther E. Rothenberg, "Toward a National Hungarian Army: The Military Compromise of 1868 and Its Consequences," Slavic Review 31 (1972): 805-16; László Péter, "The Army Question in Hungarian Politics 1867-1918," Central Europe 4 (November 2006): 88. 
other things, used in all correspondence with civilian authorities. In this regard, the military was scarcely more flexible than in the case of the command language. When some local administrations started using non-German languages in their correspondence with the military, the Ministry of War closely monitored the situation and prepared exhaustive instructions. The main point was that German should and would remain the language of all official correspondence. ${ }^{40}$ Still, the changes in the civilian sphere could not be totally ignored and the use of bilingual correspondence was allowed in a limited number of cases. Again, Hungarian was a special case, as Hungarian politicians managed to squeeze some minor additional concessions out of the emperor after the constitutional crisis of 1903. However, for the most part he was not ready to appease the Hungarians and had been seriously considering an armed intervention rather than granting more wide-reaching concessions. ${ }^{41}$ Clearly, what was at stake in the case of the administrative language was actually not administration-although there is no doubt that maintaining a single administrative language made the job of military bureaucrats easier - but rather the symbolic value of German. A single administrative as well as command language was perceived as a symbol of unity by the emperor and the military, and all attempts to replace them were interpreted as attacks on one of the last bulwarks of empire.

Considering the fact that their own national languages also had a huge symbolic value for all non-German nationalists, one cannot be surprised that they often perceived the army as a German institution, a supposed pillar of German supremacy. This attitude was manifest in Slovene nationalists too. For example, in 1909 Slovenec [Slovene], the daily of the dominant Slovene People's Party, stated that there is "a lot of German national spirit in the army."42 More than two decades earlier the liberal daily Slovenski narod [Slovene nation] had been even more direct: the German command language was presented as a

40 Österreichisches Staatsarchiv, Vienna, Kriegsarchiv (KA), War Ministry Records (KM), Präs, 50-9/1-6, 1907 and Präs, 50-9/2, 1908.

41 Norman Stone, "Constitutional Crisis in Hungary, 1903-1906," The Slavonic and East European Review 45, no. 104 (1967): 163-182. Péter, "The Army Question," 97-100; R.J.W. Evans, "Language and State Building: The Case of the Habsburg Monarchy," Austrian History Yearbook 35 (2004): 18, 19. On the plans for an armed intervention in Hungary, see Kurt Peball and Gunther E. Rothenberg, "Der Fall 'U': Die geplante Besetzung Ungarns durch die k.u.k. Armee im Herbst 1905," in Aus drei Jahrhunderten: Beiträge zur österreichischen Heeres- und Kriegsgeschichte von 1645-1938, vol. 4 of Schriften des Heeresgeschichtlichen Museums in Wien (Vienna, Munich: Bundesverlag, 1969), 85-126.

“Novega duha v armado!" [New spirit into the army!], Slovenec, 19 August 1909, 4. 
means toward the Germanization of Austrian Slavs. ${ }^{43}$ By contrast, though, the relations between the army and Slovenes in Ljubljana-Laibach were rather good. There were sporadic conflicts, even violent ones, but in general the situation was unexpectedly calm. According to Heinrich Wieden von Alpenbach, an officer stationed there in the years 1893 to 1894, 1901 to 1904, and 1908, the town was military-friendly and the rapport with civilians "excellent."44 The use of German by the military was rarely problematized on the local level and Slovene municipal politicians tried a number of times to lure additional units and headquarters to the town. Naturally, the question arises: How was such action even possible given the important role the Slovene language played in the nationalist mindset? How can we explain this apparent paradox, especially if we take into account nationalists' constant criticism of the use of German or even of bilingualism by other state institutions, such as the railways and the post?

First, let us remind ourselves that even when Slovene nationalism was one of the major factors that shaped the attitudes of the inhabitants of LjubljanaLaibach towards the German language, it was not the only one. We have already seen that a pragmatic outlook on language use had not been totally eradicated by nationalist exhortations. On the one hand, some were simply not bothered by German, or were even convinced that German and the army were a natural fit. Some Slovene-speaking veterans, for example, had no problem accepting German as the military language of command even as late as $1908 .^{45}$ On the other hand, there were others who were not oblivious to the benefits that a large garrison brought, even if they supported the Slovenification of the town in principle. After all, at the time the military represented almost 7 percent of the city's population. ${ }^{46}$ All of the soldiers had to be fed, dressed, housed, and entertained. As a result, the innkeepers, property owners, tailors, theater managers, brothel owners, and many others had a lot to lose if the military were to be chased out of the town.

43 M. D-r., "Avstrijski Nemci in ravnopravnost" [Austrian Germans and equality], Slovenski narod, 19 January $1886,1,2$.

44 KA, Nachlaß Wieden von Alpenbach (B/30:1), Heinrich Wieden von Alpenbach, "Lebensgeschichtliche Skizze," unpublished manuscript, sheet 6, 2-4. See also the chapter "Ljubljansko meščanstvo in častniki" [Townspeople of Ljubljana and officers], in Stergar, "Vojski prijazen in zaželen garnizon," 32-37.

45 Rok Stergar, "National Indifference in the Heyday of Nationalist Mobilization? Ljubljana Military Veterans and the Language of Command," Austrian History Yearbook 43 (2012): $45^{-} 58$.

46 The population of Ljubljana-Laibach in 1900 was 39,139, and of these 2,592 (6.62 \%) were officers, NCOs, or soldiers. Gemeindelexikon von Krain, 2. 
In fact, in these regards even Slovene nationalists could be more pragmatic than their front-page editorials, campaign speeches, programs, and declarations illustrate. The municipal council of Ljubljana-Laibach, in which first the united National Party and later the liberal nationalists, the National Progressive Party, had a clear majority from 1882, regularly approved funds for the construction of barracks and petitioned the authorities to move additional troops and military institutions to the town. In 1898 , for example, the council tried unsuccessfully to persuade the War Ministry to relocate the command of the 3 rd Corps from Graz to Ljubljana-Laibach. ${ }^{47}$ In fact, even when the National Party was still in opposition and the Germans held a majority in the municipal council, Slovene nationalists made the construction of new barracks and an enlargement of the garrison one of the key points in their election campaigns in 1880 and 1881. They accused the "Germans" of incompetence because they could not recruit additional units to the town, and promised voters that they would do much better. The language question was never even mentioned in this context, even though Slovene nationalists had otherwise promised the Slovenification of the town. ${ }^{48}$ Nationalists clearly knew that the army was not going to budge in this regard, but were nonetheless eager to expand the military presence. The so-called "pillar of German domination" was apparently more than welcome as long as it also supported the local economy. Such pragmatism was no exception: Italian nationalists in Trento (Trient) also put more emphasis on the economic benefits that the military generated than on ideology. ${ }^{49}$

However, there is another aspect to consider in regard to Slovene nationalists and their surprising tolerance of the German-speaking army. To further understand the reasons behind it, we must widen our focus and look at a peculiarity of Slovene politics during the constitutional era. Most Slovene politicians made great effort to emphasize their loyalty to the emperor and the Habsburg dynasty, hoping that this would help them realize their goals, and hence appeared as military-friendly as possible because it was perfectly obvious that the armed forces were especially dear to Francis Joseph..$^{50}$ That is why

47 KA, KM, Präs, Sachregister, 1898, keyword "Laibach." The relevant document KM, Präs, $25^{-3}, 1898$, has not been preserved.

48 Rok Stergar, Slovenci in vojska, 1867-1914: Slovenski odnos do vojaških vprašanj od uvedbe dualizma do začetka 1. svetovne vojne [The Slovenes and the army, 1867-1914: Slovene attitudes regarding military matters from the introduction of Dualism until the beginning of the First World War] (Ljubljana: Historia, 2004); See the chapter "Vmesna epizoda: boj za ljubljansko garnizijo" [An interim episode: The battle for the garrison of Ljubljana], $156-64$.

49 Fontana, "Trient als Festungs- und Garnisonsstadt," 184-6, 197.

50 Stergar, Slovenci in vojska, passim; Stergar, "Fragen des Militärwesens in der slowenischen Politik 1867-1914," Österreichische Osthefte 46 (2004): 391-422. 
Slovene MPs, Catholic as well as liberal, usually voted in favor of defense bills, and why politicians and newspaper editors were even willing to speak in favor of the German command and administrative language. In short, they supported (or at least tolerated) policies they privately did not necessarily agree with, because they were trying to win over "high places," as the German-language weekly Laibacher Wochenblatt smugly, but rightly, noted in $1886 .{ }^{51}$ Moreover, the coalition of the National Progressive Party, otherwise a master of nationalist outbidding, with the Germans in the Carniolan Diet (Landtag), shows that Slovene nationalists were also ready to compromise on their principles in order to outmaneuver their domestic political rivals. The coalition agreement committed the representatives of the National Progressive Party to vote for the continuation of funding for the teaching of German in Slovene-language elementary schools as well as for the German theater, but to oppose Sloveneonly street signs in Ljubljana-Laibach. ${ }^{52}$ In order to keep the Catholic National Party (after 1905, the Slovene People's Party) out of power, the liberals, who had previously declared the effort in favor of Slovene-only signs an essential part of the great battle between "haughty-pitiless Germanness and oppressed Slavism," quickly forgot such high-sounding words. ${ }^{53}$

In the case of the army's rules and regulations, political maneuvering reached its pinnacle in 1912, when the People's Party spared no effort in helping to push the new defense bill through the Reichsrat. Its MPs voted against

51 "Hardly any other phenomenon of our public life is so interesting to observe as the large fluctuations of our national parties with regard to certain government postulates, which are unpleasant to them, but which they know to be very important for the authoritative places ... The question of the use of the German language as the de facto state language and as the language of command and administration in the Army also belongs to these sensitive subjects, in which the described fluctuations can be observed particularly well." "Kaum eine andere Erscheinung unseres öffentlichen Lebens ist so interessant zu beobachten als das große Schwanken unserer nationalen Parteien gewissen staatlichen Postulaten gegenüber, die ihnen unangenehm sind, von denen sie aber wissen, daß man maßgebenden Ortes entscheidenden Werth auf dieselben legt.... Zu diesen heiklen Themen, bei denen sich das bezeichnete Schwanken besonders gut beobachten läßt, gehört auch die Frage des Gebrauches der deutschen Sprache als faktische Staatssprache und als Commando- und Dienstsprache der Armee.") "Politischer Aberwitz," Laibacher Wochenblatt, 30 January 1886, 5 .

52 Matić, Nemci v Ljubljani, 299-325; Andrej Rahten, "Der Krainer Landtag," in Die Habsburgermonarchie 1848-1918, vol. 7/2, Die regionalen Repräsentativkörperschaften, ed. Helmut Rumpler and Peter Urbanitsch, (Vienna: Verlag der Österreichischen Akademie der Wissenschaft, 2000), 1755-59: Valenčič, Zgodovina ljubljanskih uličnih imen, 97-99.

53 "Upupa Epops," Slovenski narod, 14 July 1894, 1. For more on the position of the National Progressive Party on street signs before the coalition, see Valenčič, Zgodovina ljubljanskih uličnih imen, $75^{-91 .}$ 
amendments that would have diminished the role of German in the Landwehr, and they even — as the only Slav MPs — voted against the use of non-German languages in correspondence with local authorities. One of the MPs bluntly stated: "However, not a single man has been denationalized by the common language of command. ${ }^{54}$ Not surprisingly, the Reichspost, a mouthpiece of the Belvedere Circle, was thrilled. ${ }^{55}$ All this was a demonstration of the hyper-loyal and military-friendly course that the leaders of the Slovene People's Party, convinced that the heir to the throne, Francis Ferdinand, and the army were the only forces capable of carrying out a thorough reform of the monarchy, set before the outbreak of the First World War. ${ }^{56}$

In order not to squander any potential-or imagined-political gains on the state level, Slovene nationalists had to exercise restraint on the local level. Hence, there was almost no nationalist outbidding over the use of German by the military units stationed in the town, as both parties were for the most part unwilling to risk a conflict with the military. In 1882, when the Slovene parties gained a majority in the municipal council and swiftly replaced German with Slovene in the municipal administration, correspondence with the military remained a rare but explicit exception to the new rules. The new language policy clearly stated that "the Town Hall shall communicate with the armed forces in the language of the army."57 Only after Austria-Hungary collapsed, the mayor decided of his own accord- "ex praesidio and via facti" - that all the correspondence with other offices and authorities, "including the military," should be in Slovene. ${ }^{58}$ In any case, the example of the long-time mayor of Ljubljana-Laibach, Ivan Hribar, clearly demonstrates the dangers of a less military-friendly approach. After the local commanders concluded that he was no friend of the army, they made sure that the emperor did not validate his

54 "Aber durch die gemeinsame einheitliche Kommandosprache wurde noch kein Mann entnationalisiert." SPSHAR, 21st session, 2731, 2732, 2741-2776, 2784-2809, 2820-2854, 2865-2898, 2924-2959, 2970-2978, 4406-4434, 4450-4482, 4498-4538, 4547-4591, 46oo$4659,4669-4737,4748-4778,4779-4822,4835-4850$. The quote is from p. 4430.

55 "Ein Slave für die einheitliche Armeesprache," Reichspost, 20 June 1912, 3.

56 See the chapter "Poskus iskanja zaveznikov—SLS, generali in vojaška zakonodaja iz leta 1912" [An attempt to find allies - the Slovene People's Party, the generals, and the defense bill of 1912], in Stergar, Slovenci in vojska, 220-6; Andrej Rahten, Slovenska ljudska stranka $v$ dunajskem parlamentu: Slovenska parlamentarna politika v Haburški monarhiji 1897-1914 [The Slovene People's Party in the Vienna Parliament: Slovene parliamentary politics in the Habsburg Monarchy 1897-1914] (Celje: Založba Panevropa, 2001), 105-24.

57 Zgodovinski arhiv Ljubljana [Municipal Archives of Ljubljana], Manuscript Book Collection (LJU 488), Cod III, 33, "Gemeinderaths-Sitzungs-Protokoll vom Jahre 1882," minutes for 27 October 1882 , fi36r-fi37r.

$5^{8}$ Lah, "Borba ljubljanske občine za slovensko uradovanje," 140, 142, 146. 
reelection in 1910. Consequently, Hribar, a popular and successful mayor, had to withdraw from municipal politics in order to limit the damage to his party. And this intervention was certainly not the only example of its kind: in 1912 the navy managed to bring about the suspension of the municipal autonomy of Pola (Pula) after a prolonged conflict with Italian nationalists who dominated its municipal council. ${ }^{59}$ Not surprisingly, Hribar's successor, Ivan Tavčar, made every effort to appear as military-friendly as possible. ${ }^{60}$

However, to reduce the motives for a continued acceptance of the army and its preference for German to political pragmatism would be much too reductionist. We must not forget that the overwhelming majority of Slovenes- that is Slovene nationalists-supported the continued existence of the Austrian state. They did not experience any antagonism between their Austrian state patriotism and Slovene nationalism, as anti-Austrian nationalism was a minority view even as late as the period of the Balkan Wars. ${ }^{61}$ Indeed, one of the reasons for the described deviation from nationalist orthodoxy was the awareness of the inevitable need for a compromise if the Austrian state were to survive. It must have been obvious even to most nationalists that communication within the empire was needed and that German was the most obvious if not ideal choice for that, as the future vice mayor of Ljubljana-Laibach, Karl Triller, acknowledged in a private letter in 1899 . German would be the intermediary language as long as Austria existed, and Slovenes better accept such state of affairs, he wrote. ${ }^{62}$ In effect, most Slovene nationalists came to the same conclusion as Archduke Rudolph in 1886, when he wrote that an artificial language would have been an ideal solution, but-since it was not available-German would have to do. ${ }^{63}$ After all, many politicians had personal experience from the parliament in which German was the lingua franca, although all other languages were allowed on the floor. However, as most MPs only understood their native language and German, non-German languages were rarely used. When one wanted to take part in the debate, one used German; it was the medium

\footnotetext{
59 Wiggermann, K.u.K. Kriegsmarine und Politik, 279-300.

6o Stergar, Slovenci in vojska, 210, 216-18.

61 Fran Zwitter, "The Slovenes in the Habsburg Monarchy," Austrian History Yearbook 3, no. 2 (1967): 159-88; Vasilij Melik, "Slovenci in avstrijska država 1848-1918" [The Slovenes and the Austrian state, 1848-1918], in Slovenci 1848-1918, 78-84.

62 Ivan Hribar, Moji spomini [My memoirs], vol. 1, ed. Vasilij Melik (Ljubljana: Slovenska matica, 1983-84), 407 .

63 Kronprinz Rudolf, "Skizzen aus der österreichischen Politik der letzten Jahre," in "Majestät, Ich warne Sie ...”: Geheime und private Schriften, ed. Brigitte Hamann (1979; Munich: Piper, 1987), 172, 173 .
} 
of communication, whereas the use of other languages signaled primarily a political gesture. ${ }^{64}$

To summarize, besides nationalism, pragmatism and an interest in the preservation of the Austrian state were important factors that shaped the outlook of the local population on the use of German by the army. In a way, these considerations mitigated the dogmatism of nationalist views on language and thus opened some space for the continued use of German. Hence, there was no great need for the army to change its language policy even when Slovene nationalism was in full bloom. Nevertheless, the armed forces also showed some flexibility and a willingness to acknowledge new realities, further defusing a potentially explosive situation. On the national level, the attention to the proper use of regimental languages by officers was noticeable. After all, the nationalist press and politicians, who regularly submitted interpellations against the minister of defense on such matters, would have promptly noticed any (real or imagined) disregard for non-German languages. ${ }^{65}$ Even more important for the situation in Ljubljana-Laibach was the fact that the army was increasingly prepared to use Slovene in its communication with the public; sometimes it even used Slovene in a symbolically important way.

The military used Slovene on posters, leaflets, and in newspaper announcements, although this was not a recent development. Indeed, it had used Slovene in propaganda leaflets and proclamations since as early as the French Wars. ${ }^{66}$ In such cases, the language had clearly been used to make communication with the Slovene-speaking population easier or even possible. However, the public sometimes ascribed a symbolic value to the use of a certain language even if such significance had not been intended. The messenger simply could not control how the message would be understood. A case from Celje (Cilli), a Lower Styrian provincial town with a German-speaking majority and a significant Slovene-speaking minority, excellently illustrates this point. In 1905 a noncommissioned officer, Markus (Marko) Korošec, pasted a Slovene-only poster on a military warehouse in the town. According to his account, it was intended for the merchants from the predominantly Slovene-speaking countryside. ${ }^{67}$

64 R.J.W. Evans, "Language and State Building," 15.

65 Elfriede Jandesek, "Die Stellung des Abgeordnetenhauses der im Reichsrate vertretenen Königreiche und Länder zu Fragen des Militärs, 1867-1914” (PhD diss., University of Vienna, 1964), passim.

66 Vlado Valenčič, "Slovenščina v uradih in v uradni publicistiki od srede 18. do srede 19. stoletja" [The Slovene language in official use and official publications from the mideighteenth until the mid-nineteenth century], Zgodovinski časopis 31 (1977): 334.

67 KA, KM, Präs, 50-26/1, 1905, a letter by the War Ministry, Präs. Nr. 5032, Vienna, 25 August 1905. Korošec was reprimanded because the poster was not bilingual, and at first he was 
Obviously, we cannot discount the possibility that he was a closet Slovene nationalist set on provocation, but if we believe his explanation, this was not the case. The use of Slovene had but a single purpose: communication with the Slovene speakers. Nevertheless, German nationalists clearly saw it as a symbol, a political gesture. Josef Pommer, a local MP, promptly protested to the Austrian prime minister and the Grazer Tagblatt alleged that the lone Slovene poster in Celje (Cilli) was clear evidence of the army's flirting with "Panslavic agitation." 68 What had probably been intended as a means to communicate a message was clearly perceived as a dangerous symbol by nationalists bent on preventing all attempts to challenge the dominance of German in the town. ${ }^{69}$

We can safely assume that Slovene nationalists in Ljubljana-Laibach also attributed symbolic value to similar occurrences. For example, it is fairly certain that they viewed the rare occasions in which the army used Slovene in official correspondence with local authorities as important steps in their pursuit of a complete Slovenification of local administration. Even though the commander of the 3rd Corps took great pains to explain to the War Ministry that bilingual correspondence had been just an exception necessitated by the urgency of a specific task - merely a pragmatic decision - there is no doubt that nationalists saw a large dose of symbolism in such occurrences. ${ }^{70}$

However, there were also situations when the use of Slovene had a decidedly symbolic meaning, in which it was used to show that the armed forces valued it. For example, the ranking officers in Ljubljana-Laibach regularly made an effort to appear at Slovene events to demonstrate the neutrality of the armed forces, and on these occasions they would sometimes say a few words in Slovene. The importance of such gestures should not be underestimated; in Przemyśl, for example, Polish elites were very pleased with the officers' use of the Polish language, especially when compared to the preference of local businessmen and intellectuals for German. ${ }^{71}$ The use of Slovene was

supposed to be transfered to another unit. However, someone at the ministry decided against the transfer, noting on the margins of the report: "den Alldeutschen möchte ich diese Konzession nicht machen."

68 KA, KM, Präs, 50-26/1, 1905, a letter by the Austrian defense minister Franz Schönaich to the War Ministry, Präs. No. 645, Vienna, 31 July 1905; "Die Slavisierung durch die Militärbehörde," Grazer Tagblatt, 21 July 1905 (morning ed.), 2; ibid., 23 July 1905 (morning ed.), 7 .

69 Janez Cvirn, "Jezikovna politika celjske občine na prelomu stoletja" [The language policy of the municipality of Celje at the turn of the century], Zgodovinski časopis 44 (1990): 199-214.

70 KA, KM, Präs, 50-9/1-6, 1907, a letter of the Commando of the 3rd Corps to the War Ministry, Präs. Nr. 205, Graz, 9 February 1907.

71 Fahey, "Undermining a Bulwark of the Monarchy," 151. 
also commonplace when local regiments appeared in public. In addition, the regimental band performed Slovene marches and occasionally even the unofficial national anthem. The army's adaptation to changes in the linguistic landscape was also important. In 1911, the command of the 3rd Corps and the War Ministry corresponded about a bilingual nameplate on one of the barracks in Ljubljana-Laibach, and at long last decided that it was acceptable as long as German was on top. ${ }^{72}$ The decision is a perfect illustration of the compromises that the army was willing to make in order to adjust to a shifting environment. Slovene, or any other recognized language, could be used in an official capacity, as long as German retained a privileged position.

Without a doubt, such concessions, however minor, were an indirect consequence of the sweeping changes that nationalism brought to the civilian sphere. The military simply could not afford to ignore completely the importance an ever-larger part of the population - and a number of highly influential actors - ascribed to non-German languages. However, the views of military men, specifically the officers, on the role and value of different languages also have to be considered. Clearly, the officer corps was predominantly German speaking, and there is no doubt many officers were convinced that there was a natural order to things that included a hierarchy of languages. At the same time, most of them were not German nationalists: their allegiance was to the empire and the emperor, as István Deák has shown. ${ }^{73}$ However, their supranationality often had a distinctly German flavor, as many were convinced that the German language was not only more useful, but also culturally superior. ${ }^{74}$ In many respects, the attitudes of officers were very similar to the views of the German liberal elites, who until the era of Eduard Taaffe had supported

72 KA, KM, Präs, 33-48/1, 1911. For similar cases in Cracow and Gorizia (Gorica/Görz), see: KA, KM, Präs, 50-12/1, 1907 and Präs, 33-17/1, 1912.

73 István Deák, Beyond Nationalism: A Social and Political History of the Habsburg Officer Corps, 1848-1918 (Oxford: Oxford University Press, 1990); compare R.J.W. Evans, "Unwarlike Warriors," The New York Review of Books, 16 August 1990, 47-50, and Lothar Höbelt, "Kein Bismarck und kein Moltke: Regierung, Militär und Außenpolitik in Österreich-Ungarn 1860 bis 189o," in Das Militär und der Aufbruch in die Moderne 1860 bis 189o: Armeen, Marinen und der Wandel von Politik, Gesellschaft und Wirtschaft in Europa, den USA sowie Japan, ed. Michael Epkenhans and Gerhard P. Groß (Munich: Oldenbourg, 2003), 80.

74 Antonio Schmidt-Brentano, "Die österreichische beziehungsweise österreichischungarische Armee von Erzherzog Carl bis Conrad von Hötzendorf," in Österreich und die deutsche Frage im 19. und 20. Jahrhundert: Probleme der politisch-staatlichen und soziokulturellen Differenzierung im deutschen Mitteleuropa, ed. Heinrich Lutz and Helmut Rumpler, vol. 9 of Wiener Beiträge zur Geschichte der Neuzeit, ed. Grete Klingenstein et al. (Vienna: Böhlau, 1982), 247, 248; Laurence Cole, Military Culture and Popular Patriotism in Late Imperial Austria (Oxford: Oxford University Press, 2014), 321, 322. 
the supranational state as long as it upheld the continued dominance of the German language and understood Germanness as a final stage in the personal growth of non-Germans. ${ }^{75}$ Like-minded officers equated the German language with Austrian patriotism; hence, they were convinced that Slovene usage was an indisputable sign of Russophilia, or they supported state funding of German schools in the predominantly Italian Gorizia (Gorica/Görz), to give but two examples. ${ }^{76}$ Not surprisingly, then, they opposed any changes to the rules and regulations that would give non-German languages a greater role in the military. Indeed, some even tried to reduce the usage of other languages in opposition to the existing guidelines. In 1873, for example, the officers of the 7 th Infantry Regiment from Klagenfurt (Celovec) petitioned the War Ministry for an exemption from the obligatory use of Slovene as a regimental language. They argued that most Slovene-speaking soldiers already understood German and the rest could learn it quickly, and therefore Slovene was not needed. Besides, they insisted, the unit traditionally had a "German character."77

Then again, there were also officers who understood that the times had changed. They were certainly not ready to meet all nationalist demands, but they were ready to evolve and adapt. Let me give just one example relating to Ljubljana-Laibach. When the War Ministry was preparing its opinion on the proposal of the Carniolan Diet to replace bilingual town signs with Slovene ones, the officer in charge of the case wrote a remark on the margins of his report. He proposed that the military stop supporting German at all costs and face reality — stop supporting shipwrecked policies and instead provide for better maps, was his suggestion. ${ }^{78}$ In the end he did not prevail, but his remarks are

75 Pieter M. Judson, "Inventing Germans: Class, Nationality, and Colonial Fantasy at the Margins of the Hapsburg Monarchy," Social Analysis: The International Journal of Social and Cultural Practice 33 (September 1993): 49, 50; Ian Reifowitz, "Threads Intertwined: German National Egoism and Liberalism in Adolf Fischhof's Vision for Austria," Nationalities Papers 29 (2001): 441-58. On the arrival of Taaffe as a watershed, see also Jörg Kirchhoff, Die Deutschen in der österreichisch-ungarischen Monarchie: Ihr Verhältnis zum Staat, zur deutschen Nation und ihr kollektives Selbstverständnis (1866/67-1918) (Berlin: Logos, 2001), 63-70.

76 On the use of Slovene, see Karel Clarici, Knjiga moje mladosti [The book of my youth], ed. and trans. Marjan Mušič (Ljubljana: Slovenska matica, 1981), 101, 102. On German schools in Gorizia (Gorica/Görz), see: KA, KM, Präs, 31-24/1, 1912, a letter of the command of the 3 rd Corps to the War Ministry, Präs. Nr. 787, Graz, 23 February 1912.

77 The petition and its rejection are preserved in the correspondence of Andrej Komel, an Austrian officer and a prolific author of Slovene military manuals. Narodna in univerzitetna knjižnica (National and University Library), Ljubljana, Department of Manuscripts, Ms. 1387 .

78 KA, KM, Präs, 50-12/1, 1913, a report of the War Ministry, Präs. Nr. 812, Vienna, 24 January 1913 . 
an important indication of developments within the army. For some officers it was not self-evident that the status quo enshrining the privileged position of German had to carry on indefinitely. Such officers were a minority and their influence on decision-making was not great, but they may have helped to ease the transition into a new era. Furthermore, their very existence indicates that there was the potential for an even more flexible attitude of the armed forces.

In conclusion, the armed forces, traditionally multilingual to some extent, certainly did alter their linguistic practices as the situation in LjubljanaLaibach changed. The army did not only use Slovene in its communication with the Slovene-speaking public, but also willingly employed it in a symbolically important way, for example, on the nameplates of barracks. Thus, the dominant role of German did erode slightly as the army acknowledged the change that Slovene nationalism and its emphasis on the Slovene language had brought to the town. However, as the relative importance of Slovenes was not very large and because Slovene nationalism was rather moderate, the modifications that the military undertook did not have to be extensive. German retained its dominant position, whereas Slovene was used a bit more often, but as a secondary language.

Alternatively, it seems that the willingness of Slovene nationalists to compromise actually had a more noticeable impact on the pace of the Slovenification of Ljubljana-Laibach. Whereas radical Italian nationalists in Pula (Pola), to name but one example, did not shrink from conflict with the military and relentlessly pursued their nationalizing goal-a monolingual Italian townSlovene nationalists were much more ready to appease the military. ${ }^{79}$ That is why, for example, the municipal administration still used German in correspondence with the military while at the same time they were engaged in a bitter dispute with the provincial governor over his use of German in official communication.

To reiterate, in Ljubljana-Laibach the pragmatism of the population and a number of factors that lessened the zeal of nationalists - mostly political tactics but also a genuine interest in the preservation of the Austrian state-combined to prevent the emergence of an unresolvable conflict between Slovene nationalists and the army on the role and use of languages. The flexibility of the army, although very limited, also helped. Even though their points of view were seemingly incompatible, the army and the Slovene nationalists managed to find a modus vivendi because they both acted pragmatically. This feature of Slovene nationalists further confirms recent assertions that in the Habsburg Monarchy ethnic nationalisms were not necessarily centrifugal, and that a 
more nuanced interpretation of their attitude toward the Habsburg state is warranted. ${ }^{80}$ In addition, the pragmatism of inhabitants in general is additional evidence that nationalism, while a powerful ideology, was still just "a perspective on the world," to use the words of Rogers Brubaker. ${ }^{81}$ It demonstrates once again that national indifference, bilingualism, Austrian patriotism, dynastic loyalty, and similar practices and attitudes were very much present in an era that was long interpreted as a time of triumphant nationalisms. ${ }^{82}$

80 Laurence Cole and Daniel L. Unowsky, "Introduction," in The Limits of Loyalty: Imperial Symbolism, Popular Allegiances, and State Patriotism in the Late Habsburg Monarchy, ed. Laurence Cole and Daniel L. Unowsky (New York: Berghahn Books, 2007), 2, 3.

81 Rogers Brubaker, "Ethnicity without Groups," in Ethnicity without Groups (Cambridge: Harvard University Press, 2004), 7-27.

82 There is a growing body of literature on these phenomena. Besides Deák, Cole and Unowsky, see Pieter M. Judson, Guardians of the Nation:Activists on the Language Frontiers of Imperial Austria (Cambridge: Harvard University Press, 2006); Kai Struve, "Polish Peasants in Eastern Galicia-Indifferent to the Nation or Pillars of Polishness? National Attitudes in the Light of Józef Chałasiński's Collection of Peasant Youth Memoirs," Acta Poloniae Historica 109 (2014): 37-59; Daniel L. Unowsky, The Pomp and Politics of Patriotism: Imperial Celebrations in Habsburg Austria, 1848-1916 (West Lafayette: Purdue University Press, 2005); Tara Zahra, "Imagined Noncommunities: National Indifference as a Category of Analysis," Slavic Review 69, no. 1 (2010): 93-119; Zahra, Kidnapped Souls: National Indifference and the Battle for Children in the Bohemian Lands, 1900-1948 (Ithaca: Cornell University Press, 2008). For the Slovene case, see Stergar, "National Indifference." 